\title{
Análise da composição de títulos e manchetes do diário Olé durante a cobertura das Copas do Mundo de 2014 e 2018
}

\author{
Analysis of the Composition of Olés Titles and Banner Headlines \\ during the Coverage of 2014 and 2018 FIFA World Cups
}

\author{
Mauro César Silveira \\ Universidade Federal de Santa Catarina (UFSC), Florianópolis/Brasil \\ Doutorado em História Ibero-americana, PUC-RS \\ Matheus Simões Mello \\ Universidade Federal de Santa Catarina (UFSC), Florianópolis/Brasil \\ Doutorando em Jornalismo, UFSC \\ senso_de_humor@hotmail.com
}

\begin{abstract}
RESUMo: Este artigo visa analisar a composição de títulos e manchetes dos textos publicados no diário argentino Olé durante a cobertura das Copas do Mundo de 2014 e 2018, dando ênfase àqueles formados por jogos de palavras ou com tom irreverente. Ao todo, 62 exemplares compõem o corpus desta investigação. Norteia-se metodologicamente através de mecanismos analíticos da Análise Pragmática da Narrativa Jornalística, proposta por Luiz Gonzaga Motta. Fundamenta-se teoricamente com obras que refletem acerca da linguagem jornalística esportiva, a estrutura de chamadas de textos no jornalismo esportivo e os elos entre emoção e a editoria de esportes.
\end{abstract}

PalaVRas-CHAVE: Jornalismo esportivo; Títulos; Manchetes; Olé; Narrativas jornalísticas.

ABSTRACT: This paper aims to analyze the composition of titles and banner headlines of argentine newspaper Olé during the coverage of 2014 and 2018 FIFA World Cups, emphasizing those composed by puns and/or jokes. All in all, 62 editions form the empirical object of this investigation. As the main methodological proceeding, we use some analytical mechanisms of the Pragmatic Analysis of Journalistic Narratives are, idealized by Luiz Gonzaga Motta. Theorical foundation is constructed with contributions that reflect about sports journalism language, titles, banner headlines and relations between this journalistic section and emotion.

KEYwoRDS: Sports Journalism; Titles; Banner Headlines; Olé; Journalistic Narratives. 


\section{INTRODUÇÃO}

O jornalismo esportivo dota de inúmeras particularidades e interações que vez ou outra são até conflitantes com premissas consolidadas do fazer jornalístico. As íntimas e constantes relações com o entretenimento, por exemplo, é um dos pontos centrais de discussão acerca do segmento esportivo - algumas delas, aliás, põem em xeque o DNA jornalístico dessa editoria. As chamadas dos textos, tanto em capas quanto nas demais páginas dos diários esportivos, apresentam-se como um dos espaços nos quais informação esportiva e entretenimento prosperaram entrelaçados.

A vista disso, este estudo visa analisar a composição das titulações das matérias veiculadas pelo diário argentino Olé durante a cobertura das Copas do Mundo de 2014 e 2018. O objeto empírico investigado é composto por 62 exemplares do referido jornal, publicados no decorrer dos dois Mundiais mencionados. Como será explicitado adiante, somente os títulos dos textos, com foco exclusivo àqueles com tom irreverente e jogos de palavras, compõem o corpus desta pesquisa, ainda que as linhas finas e demais elementos tenham sido de fundamental importância para compreender e contextualizar as titulações.

As análises desenvolvidas, que serão detalhadas mais adiante, são respaldadas por alguns movimentos da Análise pragmática da narrativa jornalística, idealizada por Luiz Gonzaga Motta. Tendo em vista que o referido autor defende que os movimentos propostos poderão dar luz a mensagens de fundo moral e ético, intencionalmente inseridas pelo emissor, tal estrutura metodológica é de grande ajuda para o que está aqui proposto.

Este artigo está dividido em quatro partes. Num primeiro momento, traz-se uma breve discussão acerca da linguagem jornalística esportiva e da composição de títulos e chamadas dos textos em jornais impressos. Em seguida, buscamos refletir sobre as interações entre jornalismo esportivo e emoção, em voga desde os primeiros passos do referido segmento jornalístico. Depois, esmiuçamos as bases metodológicas e apresentamos nossa estrutura analítica. Por fim, explicitamos os resultados provenientes das análises. 


\section{LINGUAGEM, TÍTULOS E CHAMADAS NO JORNALISMO ESPORTIVO}

Ainda que o jornalismo esportivo dote de relevância e visibilidade no meio profissional, o número de pesquisas acadêmicas que tenham esse segmento jornalístico como objeto de estudo ainda é diminuto em terras brasileiras. Nesse sentido, a tese doutoral do pesquisador espanhol José Luis Rojas Torrijos ${ }^{1}$ é de grande ajuda na compreensão e reflexão de questões técnicas e teóricas do jornalismo esportivo. No referido estudo, Rojas Torrijos analisa manuais de redação de veículos de comunicação de língua espanhola e elabora uma sugestão de manual como conclusão de suas investigações. É justamente através de tal contribuição do referido autor que embasamos nossa discussão acerca das chamadas de produtos jornalísticos esportivos impressos.

Antes de focarmos nos títulos, contudo, entendemos ser necessário explicitar sucintamente alguns aspectos da linguagem do jornalismo, tanto em âmbito geral quanto na editoria de esportes. Visando pensar a linguagem jornalística sob uma perspectiva mais ampla, Lage ${ }^{2}$ enfatiza a eficiência da coloquialidade, que é compreendida por leitores de baixa e alta escolaridade, e adverte para o uso de adjetivos no texto jornalístico. Talvez por lidar com emoções e se relacionar assiduamente com o entretenimento, o vocabulário coloquial sugerido por Lage seja ainda mais perceptível nas páginas esportivas. Ao indicar as principais características da linguagem jornalística esportiva, Rojas Torrijos ${ }^{3}$ cita o coloquialismo como uma delas e o associa com o aparecimento de neologismos, estrangeirismos e expressões belicistas. Devido a esses e outros aspectos, o jornalismo esportivo e seu caráter coloquial e emotivo interage de maneira tênue com abordagens sensacionalistas e apelativas, tema que será abordado no próximo item.

Castañon Rodríguez ${ }^{4}$ identifica três instâncias principais da linguagem jornalística esportiva: a) técnica, condizente às terminologias específicas do futebol (ou outra modalidade); b) de difusão, inerente às expressões responsáveis

\footnotetext{
${ }_{1}^{1}$ ROJAS TORRIJOS. Bases para la formulación de un libro de estilo de última generación.

${ }^{2}$ LAGE. Linguagem jornalística, p. 37-40.

3 ROJAS TORRIJOS. Bases para la formulación de un libro de estilo de última generación, p. 309.

${ }^{4}$ CASTAÑON RODRÍGUEZ. Universidad, Comunicación y Lenguaje Periodístico en América y España, p. 4.
} 
por tornar a comunicação mais eficiente; c) literária, concernente às palavras que interagem artisticamente com o receptor. Tais instâncias são de grande importância para o desenvolvimento desta investigação, seja numa contribuição um pouco mais clara da linguagem do jornalismo esportivo, nas discussões acerca de relatos emotivos no segmento esportivo ou na elaboração da estrutura analítica utilizada. De qualquer forma, podemos esboçar que a instância literária, ao mesmo tempo em que é um dos pontos centrais de divergências sobre as coberturas esportivas, ${ }^{5}$ é alternativa essencial para possibilitar a inserção de títulos e chamadas de textos jornalísticos como as que são aqui analisadas.

Em sua sugestão de manual de redação para veículos de língua espanhola, Rojas Torrijos ${ }^{6}$ expressa que o título deve ser "claro, direto e atrativo"7 e que deve ser uma síntese do que está no primeiro parágrafo (lide) do texto. Ao mesmo tempo em que destaca o caráter atraente de uma chamada noticiosa, adverte que a mesma não pode ser ambígua e cometer excesso na inserção de sinais de pontuação (pontos, vírgula, ponto e vírgula, exclamação, interrogação, reticências). Os jogos de palavras nos títulos podem ser utilizados, de acordo com Rojas Torrijos, em gêneros com mais leveza, como, por exemplo, as crônicas.

Os parâmetros e sugestões indicadas por Rojas Torrijos, a priori, não condizem com o que é praticado nas capas e demais páginas não só do Olé, mas também de outros diários esportivos ao redor do mundo. Podemos exemplificar com um caso brasileiro: Lance!, jornal de esportes com maior tiragem no Brasil, possui relações editoriais bastante evidentes com o Olé, que inclusive serviu de inspiração para o desenvolvimento da referida publicação brasileira, como indica Stycer ${ }^{8}$ e pesquisa anterior no qual esses diários foram comparados. ${ }^{9}$

Em parte considerável das publicações, os títulos de Olé são compostos por jogos de palavras, sejam eles neologismos ou trocadilhos com os mais variados tipos de associações. Muitos deles são pontuados por interrogações, exclamações e reticências. Tal composição faz com que as principais informações do fato

\footnotetext{
${ }^{5}$ MELLO. Hermanos y cercanos, pero no mucho, p. 104.

${ }^{6}$ ROJASTORRIJOS. Bases para la formulación de un libro de estilo de última generación, p. 102-104.

7 Tradução minha.

${ }^{8}$ STYCER. História do Lance!.

${ }^{9}$ MELLO. Hermanos y cercanos, pero no mucho.
} 
esportivo estejam inseridas na linha fina, sendo esta maior do que comumente se vê em jornais brasileiros. ${ }^{10}$ Nesse contexto, todos os elementos da página (título, linha fina e imagem/imagens), seja na capa ou nas demais páginas, acabam por transmitir as principais informações do ocorrido para o receptor. Além disso, em que pese ao imediatismo de outros meios como internet, rádio e televisão, provavelmente os leitores de Olé irão se deparar com materiais condizentes a acontecimentos cujos principais dados já são de conhecimento destes - sobretudo se levarmos em conta o corpus desta pesquisa, concernente às edições veiculadas durante Copas do Mundo.

Considerando a desvantagem dos diários perante aos meios digitais e audiovisuais no quesito rapidez de difusão dos conteúdos, é preciso mencionar outro ponto que nos ajuda a compreender a maneira como Olé monta seus títulos e chamadas. Nos últimos anos, as assessorias de imprensa dos clubes e seus dirigentes têm restringido o acesso dos jornalistas às dependências do clube e, por conseguinte, seus funcionários (atletas, técnico e demais membros da comissão técnica, executivos, diretores...). Assim, as entrevistas coletivas e zonas mistas, ambientes nos quais os repórteres têm pouco tempo para fazer perguntas a indivíduos cada vez mais reservados e treinados em suas respostas, acabam por deixar os produtos jornalísticos esportivos bastante similares, independentemente da mídia utilizada.

Dessa forma, focar na instância artística, para um veículo que só irá repercutir as informações de hoje no dia seguinte, é um dos únicos caminhos possíveis para se manter competitivo no mercado. E é justamente por isso que tais publicações são frequentemente associadas como sensacionalistas, parciais e emotivas. Nomenclaturas que geram debates no jornalismo esportivo argentino, brasileiro e internacional.

${ }^{10}$ MELLO. Hermanos y cercanos, pero no mucho, p. 86-88. 


\section{JORNALISMO ESPORTIVO E EMOÇÃO}

Ainda que, como foi dito acima, emoção e jornalismo esportivo gerem discussões em várias localidades, é necessário fazer algumas ponderações históricas a respeito da trajetória jornalística esportiva no Brasil e na Argentina. Enquanto brasileiros foram fortemente influenciados pelo modelo norte-americano (objetivo e com técnicas como o lide e a pirâmide invertida), os argentinos mantiveram um estilo menos objetivo e mais próximo ao que se verifica na Espanha (produções mais adjetivadas, não tão diretas).

Com isso, publicações com maior liberdade emotiva prosperaram em terras argentinas, ao passo que textos mais próximos aos cronistas Nelson Rodrigues e Mário Filho, duas referências da editoria de esportes, ficavam cada vez mais restritos aos espaços de crônica, coluna e opinião. Nesse contexto, a Argentina presenciou o sucesso duradouro de uma das publicações mais relevantes não só do país vizinho, mas de todo o mundo: a revista El Gráfico, veiculada pela primeira vez em 1919, que serviu de inspiração para demais produtos jornalísticos especializados em esporte ao redor do mundo, sendo reconhecida como "a bíblia do esporte". ${ }^{11}$ Ainda que não detenha o mesmo prestígio de outrora, El Gráfico permanece na história do jornalismo esportivo argentino como referência na cobertura de esportes.

Dentre as tantas publicações influenciadas por El Gráfico, pode-se incluir Olé. Consequência de um caderno suplementar ao diário Clarín para a Copa do Mundo de 1994, Olé vai às bancas pela primeira vez em 1996. Mesmo com a consolidação das transmissões televisivas de futebol em solo argentino a partir do fim de 1980 - condição que, aliás, contribuiu para o declínio de El Gráfico -, Olé contou com respaldo massivo de seu fundador para sua rápida consolidação: o Grupo Clarín, um dos maiores conglomerados comunicacionais do mundo. Retaguarda que, por exemplo, o diário Lance! não dispôs durante seus primeiros anos, resultando em inúmeras crises e distanciamento da linha editorial do Olé. ${ }^{12}$ Assim sendo, Olé é bem resguardado para propor modelos que, a priori, vão de encontro

\footnotetext{
${ }^{11}$ LÓPEZ; LÓPEZ. Primeros apuntes de la historia del periodismo deportivo en Argentina, p. 4-6.

${ }^{12}$ MELLO. Hermanos y cercanos, pero no mucho, p. 156-161.
} 
com premissas jornalísticas difundidas em terras tupiniquins, o que por vezes é confundido com demonstração de "mau jornalismo" ou menor grau de seriedade.

É importante ponderar, no entanto, que a elaboração de relatos emotivos não quer dizer necessariamente que os produtos sejam menos informativos, sérios e de menor qualidade. Durante minha pesquisa de Mestrado, ${ }^{13}$ procurei discutir temas como objetividade, parcialidade e imparcialidade no jornalismo esportivo. $\mathrm{Na}$ referida investigação, adverti para o problema de condenar produções fortemente emotivas com a prática de um mau jornalismo, já que o conceito basilar de objetividade se refere aos métodos de apuração e não ao texto em si. ${ }^{14}$ Para Grijelmo, citado por Rojas Torrijos, ${ }^{15}$ um produto pode simultaneamente ter um viés sensacionalista e cumprir com parâmetros éticos e técnicos. Dessa forma, e reiterando o caráter emotivo concernente aos acontecimentos esportivos, o jornalismo esportivo não pode ser visto apenas como jornalismo especializado, mas como uma editoria com particularidades especiais. ${ }^{16}$

Nesse sentido, considerar que um indivíduo identificado emocionalmente com o fato esportivo (com um atleta, com uma determinada equipe, ou simplesmente com a modalidade) não está apto a enxergá-lo com clareza e interpretá-lo com sobriedade é, antes de tudo, uma ofensa ao próprio receptor do conteúdo jornalístico de esportes. Ademais, trata-se de um ponto de vista ingênuo, visto que os jornalistas pretensamente isentos dotam de suas preferências clubísticas. A opção de jornalistas por enturvar suas paixões futebolísticas, ainda que muito presente na editoria de esportes, parece estar perdendo força justamente porque parte da audiência se vê incomodada com tal postura. Nesse contexto, uma série de programas "de torcedor para torcedor", vinculados ou não às agremiações futebolísticas, vêm ganhando notoriedade e se mostrando uma alternativa inclusive para graduados em Jornalismo. Mesmo que alguns desses produtos jornalísticos esportivos se excedam em alguns momentos, seja por demonstrações demasiadamente inflamadas de amor/ódio ou por defender a todo custo os clubes do qual falam, partilhamos da ideia que tal formato possui

\footnotetext{
${ }^{13}$ MELLO. Hermanos y cercanos, pero no mucho.

${ }^{14}$ KOVACH; ROSENSTIEL. Os elementos do jornalismo, p. 116-117.

${ }^{15}$ ROJAS TORRIJOS. Bases para la formulación de un libro de estilo de últimas generación, p. 322.

${ }^{16}$ ROJAS TORRIJOS. Bases para la formulación de un libro de estilo de últimas generación, p. 22.
} 
qualidades e relevância do ponto de vista jornalístico. Desprezar a importância de tais materiais para o bom desempenho do jornalismo é cometer equívoco similar à crença de que materiais pretensamente esportivos não carregam traços emotivos de maneira implícita.

No que diz respeito aos produtos jornalísticos esportivos com viés pretensamente mais objetivo, é importante elucidar algumas contribuições de Motta para refletir acerca desses materiais. Ao abordar as estratégias comunicativas necessárias no processo de construção da narrativa jornalística, o referido autor expressa que o jornalista "opera constantemente um processo de de-subjetivação do real", o que despista e camufla sua função de narrador do ocorrido. ${ }^{17}$ Nesse sentido, a busca por um relato objetivo e neutro não acaba por eliminar as preferências e emoções futebolísticas com as quais o jornalista, inevitavelmente, convive diariamente. Então, por maior esforço que um emissor venha a ter para aniquilá-las por completo, vestígios de tais sentimentos, mais ou menos evidentes, poderão ser identificados pelo pesquisador. Essas pistas emotivas podem ser encontradas não só nas escolhas de expressões e na composição textual, mas também nos enfoques utilizados, na atenção demasiada para aspectos condizentes a um dos dois clubes que se enfrentam em uma partida, dentre tantos outros aspectos que trarão sinais se bem averiguados. ${ }^{18}$

Evidentemente, não almejamos, de forma alguma, condenar ou vangloriar publicações mais ou menos objetivas, com maior ou menor peso emotivo. Atentamos, contudo, para a presença da emoção em todos eles. Como indiquei anteriormente, ${ }^{19}$ o futebol e as demais modalidades esportivas despertam as mais variadas emoções nos aficionados e interessados, independentemente dos veículos jornalísticos. Estes que, salvo exceções, apenas as registram e as transmitem aos receptores das informações.

\footnotetext{
${ }_{17}^{17}$ MOTTA. Análise Pragmática da Narrativa Jornalística, p. 155.

${ }^{18}$ MELLO. Complexidades identitárias em Santa Catarina, p. 8.

${ }^{19}$ MELLO. Hermanos y cercanos, pero no mucho, p. 128-136.
} 
Enclausurar-se em meio às informações, desprezando aquilo que é sentido por jogadores, comissão técnica e demais presentes, significa não informar ao público as consequências imediatas do fato esportivo, tornando o material incompleto. Ao mesmo tempo, interpretar erroneamente a reação da torcida e/ou buscar superdimensionar alguma reação resulta em distorção do fato, isto é, mau jornalismo. ${ }^{20}$

\section{IMPLICAÇõES METODOLÓGICAS E PROCEDIMENTO ANALÍTICO}

Como já foi mencionado no início deste artigo, utilizamos como respaldo metodológico a Análise Pragmática da Narrativa Jornalística. Esse procedimento é fundamentado a partir da narratologia, que visa entender como indivíduos "constroem seus significados através da compreensão e expressão narrativa da realidade".21 Ao todo, Motta estabelece seis movimentos de análise - sem necessidade de respeitar a ordem sugerida pelo autor - para investigar o que se pretende: a) recomposição da intriga ou do acontecimento jornalístico; b) identificação dos conflitos e da funcionalidade dos episódios; c) construção de personagens jornalísticas; d) estratégias comunicativas; e) relação comunicativa e o "contrato cognitivo" e; f) metanarrativas - significado de fundo moral ou fábula da história. ${ }^{22}$ Para os fins deste estudo, utilizaremos apenas três dos seis movimentos citados: recomposição da intriga ou do acontecimento jornalístico, identificação dos conflitos e da funcionalidade dos episódios e estratégias comunicativas.

No que tange à recomposição da intriga ou do acontecimento jornalístico, Motta expressa que o "acontecimento jornalístico" é fruto da recomposição de notícias e que o pesquisador deve atentar para ressignificações, ganchos, contextualizações e personagens. ${ }^{23}$ A definição de "acontecimento jornalístico" de Motta é bastante clara e remete a fatos de grande clamor noticioso, como, por exemplo, coberturas de eleições. No caso desta pesquisa, entendemos a Copa do Mundo como um grande "acontecimento jornalístico", competição que talvez seja o momento máximo da modalidade esportiva mais popular do mundo. Nesse contexto, todas as 64 partidas disputadas demandam atenção especial (com

\footnotetext{
${ }^{20}$ MELLO. Hermanos y cercanos, pero no mucho, p. 135.

${ }^{21}$ MOTTA. Análise Pragmática da Narrativa Jornalística, p. 144.

${ }_{22}$ MOTTA. Análise Pragmática da Narrativa Jornalística, p. 147-166.

${ }^{23}$ MOTTA. Análise Pragmática da Narrativa Jornalística, p. 147-149.
} 
destaque, por óbvio, para os confrontos nos quais o selecionado conterrâneo ao meio de comunicação está envolvido) e, por conseguinte, os fatos periféricos inerentes a treinamentos, movimentos de torcedores e tantos outros aspectos. São, pois, momentos constantes de ruptura que atrai o olhar da imprensa, esta especializada ou não em esportes.

Quanto à identificação dos conflitos e funcionalidade dos episódios, tal mecanismo analítico é útil para realçar situações que interferem no equilíbrio que está posto, seja pelo excesso ou pela falta de determinado aspecto, implícita ou explicitamente. ${ }^{24}$ Para o cumprimento dos objetivos aqui propostos, tal fase da Análise Pragmática da Narrativa Jornalística merece ainda mais atenção, visto que jogos de palavras ou títulos dos produtos jornalísticos esportivos podem fazer alusões a uma série de episódios passados (condizentes a jogadores, times, seleções, cidades, países...). Anteriormente, por exemplo, pude verificar que Olé utiliza os mais variados elementos para contextualizar e construir seus exemplares: frases de músicas ou títulos de filmes conhecidos, ditos populares, associações de proximidade com atletas e equipes estrangeiras, dentre outros. Portanto, atentar-se a tais rememorações é crucial para a compreensão tanto da anedota contida no título/manchete quanto da utilidade desta para informar e dimensionar o acontecimento jornalístico esportivo.

Por fim, debruçar-se sobre as estratégias comunicativas é um momento relevante do referido procedimento metodológico porque dá luz aos mecanismos empregados pelo emissor que escondem determinadas intenções. Ao tratar especificamente desse momento analítico, Motta faz alusão à objetividade como forma de se construir um discurso neutro e distante, como já foi mencionado acima - daí nossa opção por compor a fundamentação teórica deste estudo com discussões acerca da emoção no jornalismo esportivo. ${ }^{25}$ Ainda que, reiteramos, consideramos a emoção como uma das principais estratégias comunicativas presentes no segmento jornalístico esportivo, existem tantas outras que servem de pilar para arquitetar notícias, reportagens, colunas e demais materiais. Dar ênfase a determinada personagem e retratá-la de maneira individualizante, vocabulário,

\footnotetext{
${ }^{24}$ MOTTA. Análise Pragmática da Narrativa Jornalística, p. 149-151.

${ }^{25}$ MOTTA. Análise Pragmática da Narrativa Jornalística, p. 155.
} 
estatísticas e uso de sinais de pontuação são outros exemplos que podem contribuir para desvendar intenções se forem arduamente observados.

Norteados pelos mecanismos analíticos supracitados, optamos por analisar os títulos e manchetes através da dissociação dos elementos. Tal ação consistiu em dividir o que está presente em tais chamadas em três categorias: a) o que está posto; b) como está posto; c) associações ao que está posto. 0 primeiro grupo diz respeito ao acontecimento em si, sendo este, preferencialmente, partidas disputadas entre as seleções, enquanto o segundo é o conjunto de estratégias e contextos utilizados pelos profissionais de Olé para converter o acontecimento em conteúdo jornalístico. Por sua vez, destinamos ao terceiro grupo os fatos periféricos e rememorações consequentes do título/manchete.

Como intentamos analisar a composição de chamadas com viés irreverente e com jogos de palavras, optamos por descartar as demais publicadas em Olé durante o período já mencionado que não se enquadram em tais características. Dessa forma, é importante ressaltar que o diário argentino não publica exclusivamente títulos e manchetes com trocadilhos, sobretudo em textos menores ou com a função de reunir uma série de informações numa única notícia. Durante as Copas do Mundo de 2014 e 2018, por exemplo, pudemos verificar chamadas mais objetivas - isto é, mais próximas do que comumente se vê em produtos jornalísticos - no espaço reservado ao noticiário das agremiações futebolísticas argentinas, já que estas estavam em férias.

\section{TítUlos IRREVERENTES DE OLÉ DURANTE A COBERTURA DAS COPAS DE 2014 E 2018}

Para a exposição de alguns exemplos que ilustram os resultados decorrentes das análises, levaremos em conta a ordem temporal dos acontecimentos e a localização das chamadas no exemplar no qual foi estampada. Com isso, apresentamos exemplificações de títulos/manchetes presentes no interior das edições condizentes à Copa de 2014, enquanto aquelas referentes à Copa de 2018 são representadas somente por frases/expressões de capa.

Em 14 de junho de 2014, o repórter Bruno Sturari titulou a crônica de jogo referente à vitória do Chile sobre a Austrália por 3x1 com a frase "Scola do 
Sampa". ${ }^{26}$ Trata-se de um trocadilho mesclando o termo 'escola de samba' com o nome do então técnico do escrete chileno, Jorge Sampaoli. Seria, então, a escola de samba de Sampaoli. Nesse sentido, duas associações ao que está posto podem ser feitas: a) usa-se a figura das escolas de samba pelo fato de o torneio ter sido disputado no Brasil; b) a escola de samba, patrimônio cultural tupiniquim, remete a sentimentos como alegria, leveza e beleza, características também inerentes ao futebol brasileiro, conexão esta que pode ser sintetizada pela expressão 'jogo bonito' - que foi incorporada ao vocabulário futebolístico de outras nações. Assim, podemos entender que o referido selecionado sul-americano teve um desempenho acima da média e com tons de "jogo bonito", impressões que entram em sintonia com a linha fina e o texto de Sturari.

Quatro dias depois, em 18 de junho, Leo Farinella foi o responsável por elaborar a crônica de jogo de Brasil 0x0 México, confronto válido pela segunda rodada do Grupo A. 0 título escolhido foi "Tenía que ser el Chavo de Ochoa",27 um trocadilho que mistura o famoso seriado mexicano El Chavo del Ocho (conhecido no Brasil como "Chaves") e o nome do goleiro do México, Guillermo Ochoa. "Tenía que ser el Chavo" (ou, em português, "tinha que ser o Chaves") era uma frase recorrentemente utilizada pelas demais personagens para demonstrar descontentamento com as atitudes de Chavo, um menino ingênuo que vivia aprontando. Assim, além de associar o goleiro mexicano ao famoso programa televisivo conterrâneo, Farinella demonstrou também que as inúmeras defesas do arqueiro mencionado frustraram as pretensões do escrete canarinho, que viu seus inúmeros arremates serem defendidos por Ochoa.

Em 06 de julho, Olé publicou alguns textos acerca da histórica classificação dos argentinos para as semifinais de uma Copa do Mundo, algo que não ocorria desde 1990. A crônica principal do confronto Argentina 1x0 Bélgica recebeu o título de “¡De semi qué se siente!”.28 Tal título remete ao sentimento indescritível dos argentinos pela classificação e por voltar a ter a chance de disputar uma vaga na decisão de uma Copa do Mundo. A chamada é um jogo de palavras composto

\footnotetext{
${ }^{26}$ STURARI. Scola do Sampa, p. 16-17.

${ }^{27}$ FARINELLA. Tenía que ser el Chavo de Ochoa, p. 18-19.

${ }^{28}$ OLÉ. ¡De semi qué se siente!, p. 4-5.
} 
pela palavra semifinal (ou 'semi', como popularmente é denominada) e a frase "Decime qué se siente", concernente à canção entoada pelos argentinos durante o mundial realizado no Brasil. A canção é uma provocação aos brasileiros e tem como base a melodia de Bad Moon Rising, da banda estadunidense Creedence Clearwater Revival. Além de compilar uma série de sentimentos despertados no decorrer do certame até aquele momento, o diário argentino invocou uma melodia utilizada para versões não só futebolísticas, mas também de cunho político, como mostra Alabarces. ${ }^{29}$

No que tange às capas referentes às edições veiculadas durante a cobertura da Copa do Mundo de 2018, Olé optou pela manchete "Crisislandia"30 para retratar o empate entre Argentina e Islândia por 1x1, partida que marcou a estreia de $L a$ Selección no torneio. 0 termo é um trocadilho que mescla as expressões crisis (crise, em português) e Islândia, país rival no referido duelo. Num primeiro momento, já se percebe que o resultado foi adverso (e até certo ponto surpreendente) e desencadeou uma crise no escrete alvi-celeste. Podemos, sendo assim, associar tal conturbação consequente do tropeço argentino à manchete, que, além do ocorrido dentro de campo, pode ser associada com as inúmeras crises vividas pelo país vizinho nos últimos anos. A Argentina seria, então, a 'terra da crise'.

Dez dias depois, em 27 de junho, Olé estampou em sua capa a frase “¡Afuera las pelotas!"31 para retratar a classificação argentina para as oitavas de final, lograda após vitória sobre a Nigéria por 2x0, sendo o segundo tento sul-americano marcado aos 41 da etapa complementar. La Selección precisava de uma combinação de resultados para garantir a classificação, o que fez com que rivais já contassem com a eliminação alvi-celeste. Nesse sentido, a frase exclamativa e repleta de carga emotiva pode ser enxergada de duas formas: a) um insulto àqueles que duvidavam que os argentinos fossem conseguir a combinação necessária para avançar no certame; b) que os jogadores demonstraram raça e garra (diferentemente do que ocorrera nos jogos anteriores), fazendo alusão à expressão "poner huevos", inerente ao vocabulário futebolístico argentino e que

\footnotetext{
${ }^{29}$ ALABARCES. Fútbol, música y narcisismo.

${ }^{30}$ OLÉ. Capa Olé, 17.06.2018.

31 OLÉ. Capa Olé, 27.06.2018.
} 
significa que se deve entrar em campo com força e encarar cada partida como se fosse a última. Com relação à segunda interpretação, nota-se que há simultaneamente duas informações expressas de maneira implícita, que La Selección teve huevos contra os nigerianos e não teve diante dos islandeses e croatas (quando perderam por $3 \times 0$ ).

Por fim, em 07 de julho, Olé reservou sua capa para abordar a derrota brasileira contra os belgas por dois gols a um, em partida válida pelas quartas de final. O título escolhido foi "no hay mal que por bien no belga",32 um jogo de palavras composto por um dito popular e a nacionalidade daqueles que eliminaram seus maiores rivais no futebol. A chamada faz alusão à frase "no hay mal que por bien no venga", algo como "há males que vêm para o bem" no português, que rememora indiretamente a eliminação argentina nas oitavas de final para a França. Portanto, o revés do escrete canarinho serviu de consolo para nossos vizinhos, assim como a expressão supracitada serve de conforto em momentos difíceis.

\section{CONSIDERAÇõES FINAIS}

Este estudo visou analisar a composição de títulos e manchetes do diário argentino Olé durante a cobertura de duas edições da Copa do Mundo, debruçando-se naquelas chamadas com tom irreverente ou jogos de palavras. Como foi visto, a instância artística da linguagem jornalística esportiva é uma das saídas encontradas pelas publicações impressas para se diferenciar e inovar perante às mídias mais imediatas. Nesse contexto, os títulos, em alinhamento com os demais compostos das páginas, acabam por expressar esse apelo artístico/emotivo, o que por vezes é encarado como sensacionalismo ou 'mau jornalismo'.

Independentemente do ponto de vista que se tenha acerca de tal estratégia de construção de chamadas, é inegável que informações podem ser transmitidas por meio de tais artifícios, estejam elas escancaradas, sutilmente expostas ou escondidas. Devemos ponderar que tais características confrontam com a

${ }^{32}$ OLÉ. Capa Olé, 07.07.2018. 
natureza clara e objetiva dos títulos dos textos jornalísticos e, de fato, não cumprem o papel de resumir o acontecimento jornalístico. No entanto, lembramos que tal frase pertence a um conjunto de elementos que constroem o material (ou os materiais) referente a uma partida ou qualquer outro fato esportivo. Isto é, o receptor terá todos os dados essenciais diante de seus olhos - em Olé, por exemplo, todas as páginas que contêm crônicas de jogo são acompanhadas com o placar, a disposição tática das equipes e informações de cartões recebidos, jogadores lesionados, gols marcados, entre outras. Tendo em vista o que foi elucidado até aqui, é necessário assinalar que tal estrutura das chamadas seja de difícil compreensão aos não familiarizados ou ávidos por informação esportiva. Entretanto, trata-se de um diário especializado e que - ao que nos parece privilegia os fãs de futebol e demais modalidades.

Ao longo de sua trajetória, Olé tem sido pauta dentro e fora da Argentina por suas capas e demais chamadas para textos, tanto na versão impressa quanto em seu site.33 E, como foi evidenciado neste artigo, tais escolhas vão seguir causando debates acerca do papel do jornalismo esportivo, sua relação com o entretenimento e com a emoção.

\section{REFERÊNCIAS}

ALABARCES, Pablo. Fútbol, música y narcisismo: algunas conjeturas sobre "Brasil, decime qué se siente". El oído pensante, v. 3, n. 1, p. 1-19, 2015.

CASTAÑON RODRÍGUEZ, Jesús. Universidad, Comunicación y Lenguaje Periodístico del Fútbol en América y España. Revista Digital Universitaria, v. 6, n. 6, p. 1-12, 2005. Disponível em: < https://goo.gl/U41rpX >. Acessado em: 19 jul. 2018.

FARINELLA, Leo. Tenía que ser el Chavo de Ochoa. Olé, Buenos Aires, 18 jun. 2014.

KOVACH, Bill; ROSENSTIEL, Tom. Os elementos do jornalismo: o que os jornalistas devem saber e o público exigir. São Paulo: Geração Editorial, 2004.

\footnotetext{
${ }^{33}$ Link para o site do diário argentino: <http://ole.com.ar>. Acessado em: 23 jul. 2018.
} 
LAGE, Nilson. Linguagem jornalística. São Paulo: Ed. África, 2003.

LÓPEZ, Mariano Hernán; LÓPEZ, Andrés. Primeros apuntes de la historia del periodismo deportivo en Argentina. La Plata, Universidad Nacional de La Plata, 2011. Disponível em: < https://goo.gl/9aMo5d>. Acessado em: 20 jul. 2018.

MELLO, Matheus Simões. Hermanos y cercanos, pero no mucho: Estudo comparativo entre os jornais Lance! e Olé durante a cobertura da Copa do Mundo de 2014. Dissertação (Mestrado em Jornalismo), Universidade Federal de Santa Catarina, Florianópolis, 2015.

MELLO, Matheus Simões. Força, Chape!? Narrativas da rivalidade futebolística em jornais catarinenses antes e depois da queda do voo LaMia 2933. Congresso Brasileiro de Ciências da Comunicação, 40, Curitiba, PR, 2017.

MELLO, Matheus Simões. Complexidades identitárias em Santa Catarina: análise de narrativas jornalísticas construídas nas transmissões radiofônicas de clássicos catarinenses de futebol. Congresso Brasileiro de Ciências da Comunicação, 41, Joinville, SC, 2018.

MOTTA, Luiz Gonzaga Figueiredo. Análise Pragmática da Narrativa Jornalística. In: LAGO, Cláudia; BENETTI, Márcia (org). Metodologia de pesquisa em Jornalismo. Petrópolis: Vozes, 2007, p. 143-167.

LAGO, Cláudia; BENETTI, Márcia (org). Análise Crítica da Narrativa. Brasília: Editora da UnB, 2013.

OLÉ. ¡De semi qué se siente!. Buenos Aires, 06 jul. 2014.

OLÉ. Capa Olé 17.06.2018. Buenos Aires, 17 jun. 2018.

OLÉ. Capa Olé 27.06.2018. Buenos Aires, 27 jun. 2018.

OLÉ. Capa Olé 07.06.2018. Buenos Aires, 07 jul. 2018.

ROJAS TORRIJOS, José Luis. Bases para la formulación de un libro de estilo de última generación. Construcción de un modelo teórico válido para los medios deportivos escritos y digitales en lengua española. Tese (Doutorado em Comunicação), Universidad de Sevilla, Sevilla, 2010.

STURARI, Bruno. Scola do Sampa. Olé, Buenos Aires, 14 jun. 2014.

STYCER, Maurício. História do Lance!. São Paulo: Alameda Editorial, 2009. 